研究論文

文章からの化学物質名を含む単語の認識法の確立と化学物質名 の選択法の検討一特許公開公報を用いて

\title{
A Study for Recognition-Selection of Chemical Substance Name in Documents - Using Patent Documents
}

\author{
田中るみ子 $1^{*}$ ，中山伸一2 \\ Rumiko TANAKA ${ }^{*}$, Shin-ichi NAKAYAMA ${ }^{2}$
}

\section{1 筑波大学大学院図書館情報メディア研究科}

Graduate School of Library Information and Media Studies, University of Tsukuba

干305-8550 茨城県つくば市春日 $1-2$

E-mail: s1630517@u.tsukuba.ac.jp

2 筑波大学図書館情報メディア系

Faculty of Library Information and Media Science, University of Tsukuba

テ305-8550 茨城県つくば市春日1-2

E-mail: nakayama@slis.tsukuba.ac.jp

*連絡先著者 Corresponding Author

化学物質名は, 多様であり, 記載法も書き手に委ねられているため自動抽出が難しく化学 知識の共有化を妨げている．化学物質名を自動抽出できれば，共有化に役立つ．日本語の化 学物質名を抽出するために，化学物質名をタグ付けした特許公開公報のコーパスの作成を行 い, 文章から形態素の切り出し, 切り出した形態素の連結をすることによる化学物質名の認 識法を確立した。あわせて連結した単語群から化学物質名を選択寸る方法の基礎的な検討, 及び化学物質名と間違えやすい置換基名との選択比較も行った.

The chemical substance names described have various descriptions and the description of the name depends on the author. Such variation causes hindering information sharing of chemical knowledge. Auto-extraction of chemical substance names is useful for information sharing. In order to find a method for extracting the names of chemical substances in Japanese documents, we created a corpus of patent documents tagged with chemical substance names. We studied cutting out words from sentences and recognized chemical substance names by concatenating cut-out words using the part of speech information. We also studied selecting chemical substance names from concatenated cut-out words and made a selection comparison between chemical substance names and functional group names that are similar to chemical substance names.

キーワード：化学物質名, 化合物名, 置換基名, 特許公開公報, 情報抽出

Keywords: chemical substance name, compound name, functional group, patent publication, information extraction 


\section{1 はじめに}

私たちの生活の中で, 多くの工業製品, 医薬品, 化粧品などが化学知識を使って作 られている。これらの製品は，さまざまな 有用な用途に用いられ，生活の向上に多大 な寄与をもたらしている。また，化学知識 を用いて解決すべき環境問題やエネルギー 問題などがあり，化学知識は，問題解決の ために欠かせない知識である。

ニュース，新聞記事，科学技術文献など には,さまざまな化学に関する文章があり， そこには化学知識が包含されている。 それ らは日々膨大な数が生産され，そこに記述 される化学知識も増え続けている．化学が 扱う問題を解決するには，化学知識を将来 にわたって活用できるように効率よく抽出, 整理，蓄積することが必要であるが，それ には多大な時間と労力が必要である。そこ で膨大な文章から化学知識の自動抽出が求 められている[1].

化学知識は化学物質とその属性や構造, 機能，製造方法，化学反応，用途などから 成り立ち，その中核となるのが化学物質で ある．化学知識の抽出にはまず膨大な文章 から化学物質を表す語句を抽出することが 必要である[2].

化学物質の名称には，新しい名称が作ら れる，開発の時期により名称が変わる（医 薬品など), 命名法による表記のゆれがある， 書き手により任意の表記が用いられる，カ タカナ, 記号, 数字が多い, 複合語が多い などの特徵があるのと同時に，表記の仕方 も名称，構造式，結合表，化学式，記号な ど多様である.例えば，「䣷酸エチル」の表 記には訳語 ethyl acetate（英訳），エチルア セテート (翻字), 141-78-6 (CAS 登録番号)， $\mathrm{C}_{4} \mathrm{H}_{8} \mathrm{O}_{2}$ (分子式), $\mathrm{CH}_{3} \mathrm{COOCH}_{2} \mathrm{CH}_{3}$ (示性
式)，などがあり，単に酢エチと記載される 場合もある。このように，同一物質でも表 記が異なったり，同じ表記でも違う物質を 表したりすることから，化学物質名の認 識・選択は難しい問題となっている.

文章から化学物質名を抽出する研究は, 英文に対する研究が先行している，その理 由は，英文は単語をスペースや記号によっ て分けることができることから，単語の認 識が容易であるためと考えられる．英文か ら化学物質名を抽出寸る方法は，ルールベ 一スや機械学習，この 2 つを組み合わせた ものなどがある，福田らは，物質名を構成 する文字の特徵と周辺に現れる語句を手が かりにタンパク質名を抽出した[3]. Kemp らは，化学物質名フラグメントを備えた辞 書を用いて，特許文書中の化学物質名を人 手で作ったルールに基づいて抽出した[4]. Kemp らによれば，国際特許分類「C07D」 の 70 件の特許明細書における特定の化学 物質名 14855 の 97.4\%を抽出することがで きた. 英文からの化学物質名抽出について は，他にも医薬品開発に向けて，化学的性 質や化合物の部分構造を含めて用語の抽出 を行った研究[5] [6]や，化学物質名特有の 特徵を見出し，機械学習モデルを使って物 質名を抽出した研究[7]などがある.

海外では，化学物質名抽出のワークショ ップが活発に行われている. BioCreative

(Critical Assessment of Information Extraction in Biology) IV ワークショップ (2014） [8] では PubMedのタイトルと抄録から，さら に，BioCreative V ワークショップ (2015) [9]では特許文書から化合物，遺伝子，タン パク質などの名称を，それぞれ抽出する夕 スク (CHEMDNER (Chemical Compound and Drug Name Recognition)）が設定され，多く 
の研究グループが参加した[10]. BioCreative V のCHEMDNER タスクには, 21 チーム が参加し, 最高点は再現率 0.91 , 適合率 0.87 , $\mathrm{F}$ 值 0.89 であった. BioCreative $\mathrm{V}$ で特許文 書を対象としたのは，ノイズの多い特許文 書から化学的及び生物学的データを抽出す る方法を見出すことによって，ほかの種類 の文書においてもその方法が役立つと考え られたためである。

一方, 英文における研究と比べて, 日本 語の文章から化学物質名を抽出する研究は まだ少ない，日本語の場合は，化学物質名 を選択する前に文章から単語を認識する必 要がある. 先行研究では, 化学物質名を構 成する文字種に着目し, カタカナ, 英数,

「酸」などの漢字，括弧などが連続したも のを候補として認識した後, 機械学習を用 いて物質名としてふさわしいかどうか選択 する抽出法が報告されている[11] [12] [13]. これらは主に命名法に基づく記載に適用さ れるため, 慣用名を抽出するのは難しい.

日本語の文章から化学物質名を認識する 方法として, 形態素解析を用いる石川らの 事例がある[14]. 形態素解析は文を形態素 という意味の最小単位へ分割し, 各形態素 一品詞を付与し，各形態素を原型に復元す るという 3 つの機能を持つ. しかし，一般 的な形態素解析では, 化学物質名は途中で 分断され, 化学物質名として正しく認識で きない場合が多い. 例えば, 「1-（6-ブロ モーピリジンー3ーイルメチル）－4-エチ ルーピペラジン」や「酸化第一銅」は「1/ ー/（/6/ー/ブロモ/ー/ピリジン/ー/3/ー/イル メチル/) /ー/4/ー/エチル/ー/ピペラジン」や 「酸化/第/一/銅」のように細かく形態素に 切り出されるため, これらから化学物質名 としてひとかたまりの単語にまとめること
が必要である，石川らは，形態素解析ツー ル茶鉒（ChaSen）を用いて形態素解析を行 った後, 出力された形態素の各品詞情報を もとに, 形態素の品詞が「名詞, 未知語, 記号，接頭辞」で構成される形態素のまと まりを用語としている。このように化学物 質名の認識には，品詞情報をもとに形態素 をひとかたまりにする方法が考えられる. ただ，石川らの研究は化学物質名だけでな $く$, 手段・効果の用語も含めた関連語を認 識することを目的としており，認識の精度 については不明確であり記述されていない。 形態素をひとかたまりの単語に認識した 後, 化学物質名の選択を検討しなければな らない，その手掛かりとして，化学物質名 を構成する文字の表記, 化学物質名とその 周辺に現れる単語, 化学物質名を修飾する 単語, 化学物質名を含む文の意味など多様 な方法が考えられる.

このように，形態素解析を介して日本語 の化学物質名を抽出するには, 文章からの 形態素の切り出しと連結による化学物質名 を含む単語の認識という段階と, 得られた 単語群から化学物質名を選択するという段 階が必要である。本論では，これらの段階 についてそれぞれ検討したので結果を報告 する.

\section{2 コーパスの作成}

日本語文章中に出現する化学物質名の特 徵分析や抽出結果の妥当性を検証するため には，化学物質名をタグ付けしたコーパス が必要である，その作成には，特許公開公 報の化学分野の電子データを利用した。特 許公開公報は進歩性, 新規性を明らかにし, 発明の知的財産権を表すのに有効な文書で あり，他の科学技術文献には掲載されてい 
ないデータを持つ重要な情報源である，先 行研究でも BioCreative V などのように特 許文書を対象にしている例が多く，また特 許公開公報における化学物質名の記載は書 き手に委ねられている要素が強く, 表記が 多様であるため, 材料として適切であると 考えた.さらに，特許公開公報の電子デー タはオープンソースであり，インターネッ 卜経由で容易にダウンロードが可能である [15].

Kemp らは 70 件の特許明細書を対象にし ている[4]ことを参考に，本研究では 2016 年 7 月に公開された特許公開公報から，化 学物質名が多く記載されていると考えられ る国際特許分類「C 化学; 冶金」に該当す る公報 50 件（総文字数：1120210）を取り 出し, タイトル, 抄録, 本文に記載されて いる化学物質名に対してタグ付けを行った。 タグ付けを行った化学物質名は構造が明確 な単一物質, 複合物質, ポリマー, 混合物, 及び部分的に構造が明確な物質群であり， さらに商品名も含む. 形式的には分子式, 示性式のタグ付けは行ったが，記号の連な りである CAS 登録番号などの記号番号に は行っていない。また特許公報に頻出の $\mathrm{RNH}_{2}$ のようなマーカッシュ形式は後述の 置換基としてタグ付けを行った.

化学物質名の記載は IUPAC (International Union of Pure and Applied Chemistry）が定め る，化合物の体系名の命名法への準拠が一 般に推奨されている. 命名法は中心となる 母体（環を含むと母核と呼ばれることもあ る）化合物の水素を置換基で置き換えた誘 導体として命名される。このため, 命名法 に基づいた化学物質名は，置換基名を含ん で成り立っている．例えば塩化ビニルは化 学物質名であるが，ビニル基 $\left(\mathrm{CH}_{2}=\mathrm{CH}-\right)$
は置換基名である．化学物質名の名称が命 名法への準拠が推奨されることを考慮する と, 化学物質名の抽出の際に置換基名が混 在する影響が考えられる。

そこで化学物質名を選択する段階で置換 基名の影響を検討できるように，コーパス の作成においては，化学物質名にタグ付け $<$ chem>すると同時に, 置換基にもタグ付け $<$ group $>$ を行った. なお複数の名称をまとめ て記載した「カルシウムアルミネート及び ／又はアルカリ金属アルミン酸塩」のよう な場合，「及び」，「又は」，「及び／又は」の 前後で区切ってタグ付けした. タグ付けの 例を図 1 に示寸.

代表的なものとしては, 例えば<chem>ビニ

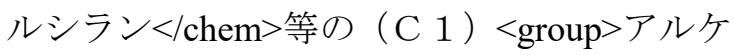
ニル基 $<$ group $>$ を有する $<$ chem $>$ 珪素含有化 合物 $</$ chem $>$ と, 例えば $<$ chem $>$ ヒドロシラン $</$ chem>等の (C 2 ) < group > ヒドロシリル基 $<$ group $>$ を含有する $<$ chem $>$ 珪素化合物 $</$ chem $>$ とを総 $<$ group $>$ ヒドロシリル基 $</$ group $>$ 量が 0 . 5 倍以上， 2 。 0 倍以下と なる量比で混合し，（C 3 ）<chem> P t $</$ chem $>$ 触媒などの付加縮合触媒の存在下反 応させて得られる<group $>\mathrm{S}$ i $-\mathrm{C}-\mathrm{C}-\mathrm{S}$ i 結合 $</$ group $>$ を架橋点に有する化合物等を 挙げることができる.

\section{図 1 タグ付け}

各特許公開公報に何個の化学物質名と置 換基名があったかは後述の表 3 に示す. 今 回タグ付けした公報は国際特許分類「C 化 学; 治金」に属しているが，化学物質名が ほとんど記載されない装置，製造，物流な どの分野もあり，化学物質名タグが付与さ れない公報もあった．全体として，<chem> タグは 15834 個，<group>タグは 2991 個付 与された。 


\section{3 化学物質名を含む単語の認識}

\section{1 方法}

日本語の文章から化学物質名を抽出する ためには，まず文章を単語単位に認識する 必要がある。この単語単位の認識は形態素 解析ツールを用いて行う。形態素解析ツー ルには JUMAN，茶鉒(ChaSen), MeCab な どがあるが，より改良され高速になった $\mathrm{MeCab}$ を用いることとする[16].

$\mathrm{MeCab}$ を用いると,「ジメチルアミノエ チルメタアクリレート塩化メチル 4 級塩の 重合物が広く使用されている.」は表 1 のよ うに形態素に認識され, 入力文字 (表層形) に続き, 品詞, 品詞細分類 1 , 品詞細分類 2 , 品詞細分類 3, 活用形, 活用型, 原形, 読 み，発音が表示される。

表 1 形態素解析の例

\begin{tabular}{|c|c|}
\hline $\begin{array}{l}\text { ジメチルラ } \\
\text { 般,*,**,*,* }\end{array}$ & アミノエチルメタアクリレート 名詞,一 \\
\hline 塩化 & 名詞,サ変接続,***,**,塩化,エンカ,エンカ \\
\hline メチル & 名詞,一般,*,*,**,* \\
\hline 4 & 名詞, 数, ${ }^{*}, *, *, *$ \\
\hline 級 & 名詞,接尾,助数詞, ${ }^{*}, *$, 級,キュウ,キュー \\
\hline 塩 & 名詞,一般,*****,塩,シオ,シオ \\
\hline の & 助詞,連体化,***,*,*,の,ノ,ノ \\
\hline $\begin{array}{l}\text { 重合 } \\
\text { ジューゴー }\end{array}$ & 名詞,サ変接続,*,*,*,*重合,ジュウゴウ, \\
\hline 物 & 名詞,接尾,一般,**,*,物,ブツ,ブツ \\
\hline が & 助詞,格助詞,一般,**,*,が,ガ,ガ \\
\hline $\begin{array}{l}\text { 広く } \\
\text { テ接続,広l }\end{array}$ & $\begin{array}{l}\text { 形容詞,自立, }{ }^{*}, * \text {,形容詞・アウオ段,連用 } \\
\text { い,ヒロク,ヒロク }\end{array}$ \\
\hline $\begin{array}{l}\text { 使用 } \\
\text { さ } \\
\text { する,サ,サ }\end{array}$ & $\begin{array}{l}\text { 名詞,サ変接続,****,*,使用,ショウ,ショー } \\
\text { 動詞,自立, }{ }^{*}, * \text {,サ変・スル,未然レル接続, }\end{array}$ \\
\hline れ & 動詞,接尾,*,*,一段,連用形,れる,レ,レ \\
\hline$\tau$ & 助詞,接続助詞,*,*,*,*,て,テ,テ \\
\hline $\begin{array}{l}\text { いる } \\
\text { イル }\end{array}$ & 動詞,非自立, *,*,一段,基本形,いる,イル, \\
\hline & 号，句点, ****,. \\
\hline
\end{tabular}

形態素から化学物質名を単語として認識 する方法を検討するため，作成したコーパ スの中から<chem>でタグ付けした化学物 質名だけを取り出し，そこに含まれる各形
態素の品詞を調べた. 化学物質名に出現し ていた品詞ののべ語数と事例, 出現箇所を 表 2に示す.

表 2 品詞の割合と例

\begin{tabular}{|c|c|c|c|}
\hline 品詞 & 語数 & 事例 & 出現箇所 \\
\hline 感動詞 & 7 & $\mathrm{Km}$ ウン & 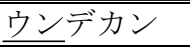 \\
\hline 記号 & 13062 & $\begin{array}{l}-B \mathrm{LCH}= \\
\mathrm{XQNR} \cdot \mathrm{ZOFBI} \\
(\sim) \quad\left[\mathrm{p}^{\prime}\right] \cdots\end{array}$ & \\
\hline 形容詞 & 0 & & \\
\hline 助詞 & 28 & デノへべん & ヘキサデシル \\
\hline 助動詞 & 0 & & \\
\hline 接続詞 & 0 & & \\
\hline 接頭詞 & 306 & 第不過 重… & \\
\hline 動詞 & 0 & & \\
\hline 副詞 & 26 & フッ ジーン & フッ化白金 \\
\hline 名詞 & 42940 & $\begin{array}{l}\text { 亜砒酸 フルオロ } \\
\text { ウラシル ホルム } \\
\text { アミド … }\end{array}$ & \\
\hline 連体詞 & 0 & & \\
\hline 総合計 & 56369 & & \\
\hline
\end{tabular}

化学物質名に付与された品詞は感動詞, 記号, 助詞, 接頭詞, 副詞, 名詞の 6 種類 であった。化学物質名を構成する要素とし て記号，接頭詞，名詞は妥当であるが，表 2 の事例に見られるように「ウンデカン」 の「ウン」が感動詞として,「フッ化白金」 の「フッ」が副詞として解析されているこ となどから, 感動詞, 助詞, 副詞は誤って 付与されたと考えられた，その原因は形態 素解析ツールのシステム辞書にウンデカン, フッ化などの形態素がないためであると考 えられる。

そこで，基本的な化学物質名の形態素を 含むユーザー辞書を作成することとした． 日本化学物質辞書 Web（日化辞 Web）[17] から RDF データ NBDC_NikkajiRDF_main. tar.gz をダウンロードし, ndl:transcription のタグのついた例えば，"4-(トリ\#イソ\#プ ロピル\#シリル\#オキシ\#)フラン\#-2-カルボ\# アルデヒド\#"のデータを\#で分割すること 
により，トリ，イソ，プロピル，シリル， オキシなどを形態素とし，最終的に 15654 の形態素からなるユーザー辞書を作成した. このユーザー辞書を用いて，化学物質名だ けを形態素解析すると, 記号 59 種類, 接 頭詞 20 種類,名詞 3106 種類という結果が 得られた。誤って付与された品詞がないこ とが確認されたことから化学物質名を構成 寸る形態素の品詞は記号, 接頭詞, 名詞で あると考え，記号，接頭詞，名詞が連続し ていた場合，それらを連結して一つの単語 とすることとした．

なお記号は「一」や「()」のように，化 学物質名の一部として使われるものもあれ ば，「。」「、」のように化学物質名の一部 にはならない句読点もある．間に「、」が入 ることもある。そのため, 連結した後に, 単語の先頭や後尾に「、酸化第一銅」のよ うに句読点がある場合，これらの句読点を 連結後に削除することとした.

\section{2 結果及び考察}

上記の方法により認識された単語群を 「Z」とし，単語群には予め夕グ付けした 化学物質名群を「C」, < group>でタグ付け した置換基名群を「G」とすると，「C」と 「G」はそれぞれ「Z」にすべて含まれてい ることを確認した。このように,ユーザー辞 書を用いた形態素解析結果を用いて，特定 の品詞を連結する後処理を行うことにより すべての化学物質名を単語として認識する ことができた，表 3 に公報ごとの全単語群 $(\mathrm{Z})$ の数, chem $(\mathrm{C})$ の数, group $(\mathrm{G})$ の数, $\mathrm{C} / \mathrm{Z}$, $\mathrm{G} / \mathrm{Z}$ を示す. 今回対象とした 50 公報の単語 のうち, 全体として一割弱の語が化学物質 名であった。
表 3 公報毎の単語数及びタグの付与頻度

\begin{tabular}{|c|c|c|c|c|c|}
\hline 公報番号 & $\begin{array}{c}\text { 全単語 } \\
\text { 群 }(\mathrm{Z}) \text { の } \\
\text { 数 }\end{array}$ & $\begin{array}{l}\text { chem } \\
\text { (C) } \sigma \\
\text { 数 }\end{array}$ & $\begin{array}{l}\text { group } \\
\text { (G) } \sigma \\
\text { 数 }\end{array}$ & $\begin{array}{l}\mathrm{C} の \\
\text { 数/Z } \\
\text { の数 }\end{array}$ & $\begin{array}{l}\mathrm{G} \sigma \\
\text { 数/Z } \\
\text { の数 }\end{array}$ \\
\hline$\overline{2016129515}$ & 11932 & 139 & & 0.012 & 0.000 \\
\hline 2016129862 & 1328 & 49 & & 0.037 & 0.000 \\
\hline 2016129882 & 3363 & 490 & 29 & 0.146 & 0.009 \\
\hline 2016129977 & 736 & 8 & & 0.011 & 0.000 \\
\hline 2016130183 & 1887 & 287 & & 0.152 & 0.000 \\
\hline 2016130193 & 6672 & 788 & & 0.118 & 0.000 \\
\hline 2016130203 & 1084 & 242 & & 0.223 & 0.000 \\
\hline 2016130213 & 1513 & 272 & & 0.180 & 0.000 \\
\hline 2016130234 & 1854 & 96 & & 0.052 & 0.000 \\
\hline 2016130249 & 11266 & 910 & 1082 & 0.081 & 0.096 \\
\hline 2016130271 & 4712 & 1041 & 164 & 0.221 & 0.035 \\
\hline 2016130281 & 3761 & 533 & 55 & 0.142 & 0.015 \\
\hline 2016130291 & 7473 & 1691 & 150 & 0.226 & 0.020 \\
\hline 2016130301 & 1505 & 345 & & 0.229 & 0.000 \\
\hline 20161 & 2188 & 209 & 1 & 0.096 & 0.000 \\
\hline 2016130321 & 5126 & 441 & 94 & 0.086 & 0.018 \\
\hline 2016130331 & 1880 & 0 & & 0.000 & 0.000 \\
\hline 2016130341 & 2256 & 294 & & 0.130 & 0.000 \\
\hline 2016130351 & 776 & 34 & & 0.044 & 0.000 \\
\hline 2016 & 1832 & 179 & & 0.098 & 0.000 \\
\hline 2016 & 1960 & 221 & 3 & 0.113 & 0.002 \\
\hline 2016130783 & 1184 & 198 & 34 & 0.167 & 0.029 \\
\hline 2016130861 & 3260 & 74 & 13 & 0.023 & 0.004 \\
\hline 2016 & 1145 & 8 & & 0.007 & 0.000 \\
\hline 2016 & 4058 & 383 & 152 & 0.094 & 0.037 \\
\hline 2014020939 & 3556 & 411 & & 0.116 & 0.000 \\
\hline 2014021084 & 2831 & 247 & & 0.087 & 0.000 \\
\hline 2014021205 & 2916 & 147 & & 0.050 & 0.000 \\
\hline 2014 & 1909 & 294 & & 0.154 & 0.000 \\
\hline 2014 & 4116 & 88 & & 0.021 & 0.000 \\
\hline 2014021351 & 6185 & 813 & 189 & 0.131 & 0.031 \\
\hline 2014021388 & 5968 & 684 & 10 & 0.115 & 0.002 \\
\hline 2014021419 & 2501 & 332 & 276 & 0.133 & 0.110 \\
\hline 201 & 2747 & 170 & 2 & 0.062 & 0.001 \\
\hline 1114 & 11677 & 188 & $\overline{33}$ & 0.016 & 0.003 \\
\hline 2016521125 & 2126 & 115 & & 0.054 & 0.000 \\
\hline 2016521195 & 4535 & 45 & & 0.010 & 0.000 \\
\hline 2016521222 & 3583 & 264 & 16 & 0.074 & 0.004 \\
\hline 2016 & 1312 & 268 & & 0.204 & 0.000 \\
\hline 2016521251 & 4718 & 545 & 494 & 0.116 & 0.105 \\
\hline 2016521262 & 5107 & 420 & 2 & 0.082 & 0.000 \\
\hline 2016521295 & 9508 & 835 & 50 & 0.088 & 0.005 \\
\hline 2016521305 & 1998 & 319 & 34 & 0.160 & 0.017 \\
\hline 201 & 3548 & 36 & & 0.010 & 0.000 \\
\hline 2016521374 & 2986 & 331 & 91 & 0.111 & 0.030 \\
\hline 2016131495 & 1203 & 75 & 3 & 0.062 & 0.002 \\
\hline 2016131516 & 1582 & 2 & & 0.001 & 0.000 \\
\hline 2016131541 & 2420 & 24 & & 0.010 & 0.000 \\
\hline 20161 & 3418 & 200 & 14 & 0.059 & 0.004 \\
\hline 2016131932 & 2403 & 49 & & 0.020 & 0.000 \\
\hline 合計 & 179604 & $\overline{15834}$ & $\overline{991}$ & "0.088 & 0.017 \\
\hline
\end{tabular}

\section{4 文字に注目した化学物質名の}

選択方法及び化学物質名と間違 えやすい置換基名との選択比較

3.で取り出した単語群には化学物質名と そうでないものが混在している，そこから 
化学物質名のみを取り出す方法として, 化 学物質名は命名法に基づいた記載が多いこ とから, カタカナ, 記号, 数字, 限られた 漢字から構成されることに着目した。 そこ で化学物質名を構成する文字の出現頻度が 認識する手がかりにならないかと考え，試 行的に化学物質名を構成する 1 文字 (1-gram)の出現頻度による方法を検討した.

\section{1 方法}

タグ付けした化学物質名群「C」に含ま れる一文字ののべ出現頻度 (n) とこの方法 で得られた全単語群「Z」に含まれる一文 字ののべ出現頻度（N）をそれぞれ数え， その比率 $(\mathrm{n} / \mathrm{N})$ を求める. $\mathrm{n} / \mathrm{N}$ が 1 以上, 0.9 以上， 0.8 以上， 0.7 以上， 0.6 以上， 0.5 以上に該当する文字のリストを作成する. $\mathrm{n} / \mathrm{N}$ が高い文字が化学物質名に特有な文字 と考え，その文字が含まれる語句をそれぞ れ「Z」から取り出し， n/Nにより<chem> でタグ付けした化学物質名の選出がどのよ うに変化するかを調べることとした。

また誤って置換基名が化学物質名として 選択されてしまう影響を検討するため, <group>でタグ付けした置換基名が各取り 出し条件においてどの程度含まれるかを調 べることとした。

全単語群 $\mathrm{Z}$ と $\mathrm{n} / \mathrm{N}$ で取り出した単語群 $\mathrm{R}$ との関係を図 2 に示す。
Z：全単語群
C: 全 chem 群
G：全 group 群
$\mathrm{O}$ ：それ以外
$\mathrm{R}$ : 取り出された単語群
c: 取り出された chem 群
g: 取り出された group 群
o: 取り出されたそれ以外

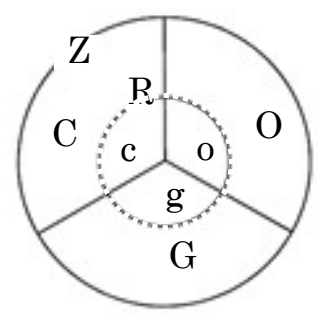

図 2 タグ付けと抽出との関係

全単語群「Z」には，化学物質名群「C」
と置換基名群「G」, それ以外の「O」が含 まれる。一文字の $\mathrm{n} / \mathrm{N}$ 別に取り出された単 語群「R」は「Z」の部分集合であり，そこ には化学物質名 $\mathrm{c}$ と置換基名 $\mathrm{g}$ とそれ以外 の o が含まれる，n/Nにより，化学物質名 と置換基名の適合率，再現率がどのように 変動するかを調べることにより，1-gramに よる方法の化学物質名選出の可能性の検討 を行うとともに, 置換基名の化学物質名選出 への影響を検討することとした。

\section{2 結果及び考察}

タグ付けした化学物質名群「C」と全単 語群「Z」に含まれる一文字の頻度の $\mathrm{n} / \mathrm{N}$ 別の文字を表 4に示す， $\mathrm{n} / \mathrm{N}$ 別に該当する 文字が含まれる語句を抽出し, 抽出された 単語の数 $\left(\mathrm{R}_{\mathrm{n}}\right)$ と抽出された単語群中の化 学物質名の数 $\left(\mathrm{c}_{\mathrm{n}}\right)$ を数え上げた. タグ付 けされた全化学物質名数 $\mathrm{C}_{\mathrm{n}}$ (15834 個)をも とに, 再現率 $\operatorname{recall}\left(\mathrm{c}_{\mathrm{n}} / \mathrm{C}_{\mathrm{n}}\right)$, 適合率 $\operatorname{precision}\left(\mathrm{c}_{\mathrm{n}} / \mathrm{R}_{\mathrm{n}}\right), \mathrm{F}$ 值を求めた結果を表 5 に, 再現率と適合率の関係のグラフを図 3にそれ ぞれ示す。

表 4 化学物質名に特有な文字

\begin{tabular}{|c|c|c|}
\hline $\mathrm{n} / \mathrm{N}$ & 個数 & 文字 \\
\hline 1 & 12 & w|苛|吉|錫|酒|藻|弗|没|酪|砒|硼|蔗 \\
\hline 0.9 & 16 & $\omega \mid$ |苛|吉|錫|酒|藻|弗|没|酪|砒|硼|蔗|酥|'|灰|硝 \\
\hline 0.8 & 21 & $\begin{array}{l}\omega \mid \text { 苛|吉|錫|酒|藻|弗|没|酷|砒|硼|蔗|酶|'|灰| } \\
\text { 硝|-|ジ|硫|六|窒 }\end{array}$ \\
\hline 0.7 & 29 & $\begin{array}{l}\omega \mid \text { 苛|吉|錫|酒|藻|弗|没|酪|砒|硼|蔗|酰|'|灰| } \\
\text { 硝|-|ゾ|硫|六|窒|亜|ホ|錯|珪|黄 }|-| \mathrm{O} \mid \alpha\end{array}$ \\
\hline 0.6 & 49 & 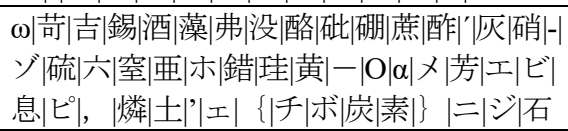 \\
\hline 0.5 & 80 & 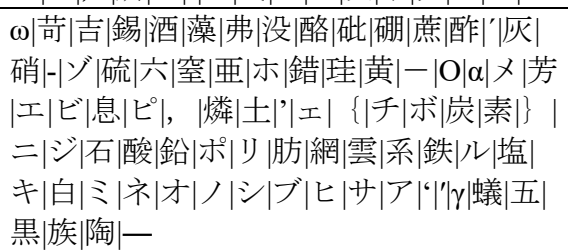 \\
\hline
\end{tabular}

$\mathrm{n} / \mathrm{N}$; 抽出された単語群中の化学物質名文字の頻度 (n) /抽出された単語群の文字の頻度 $(\mathrm{N})$ 
表 5 1-gramによる化学物質名の抽出

\begin{tabular}{|l|r|r|r|r|r|}
\hline $\mathrm{n} / \mathrm{N}$ & $\begin{array}{c}\text { 抽出され } \\
\text { た単語群 } \\
\left.\text { の数( } \mathrm{R}_{\mathrm{n}}\right)\end{array}$ & $\begin{array}{r}\text { 抽出され化学物 } \\
\text { 質の数 } \\
\left(\mathrm{c}_{\mathrm{n}}\right)\end{array}$ & $\begin{array}{c}\text { 再現率 } \\
\text { recall }\end{array}$ & $\begin{array}{c}\text { 適合率 } \\
\text { precision }\end{array}$ & $\mathrm{F}$ 值 \\
\hline 1 & 54 & 54 & 0.003 & 1.000 & 0.007 \\
\hline 0.9 & 351 & 333 & 0.021 & 0.949 & 0.041 \\
\hline 0.8 & 1575 & 1335 & 0.084 & 0.848 & 0.153 \\
\hline 0.7 & 7106 & 4276 & 0.270 & 0.602 & 0.373 \\
\hline 0.6 & 20643 & 10584 & 0.668 & 0.513 & 0.580 \\
\hline 0.5 & 36782 & 13742 & 0.868 & 0.374 & 0.522 \\
\hline
\end{tabular}

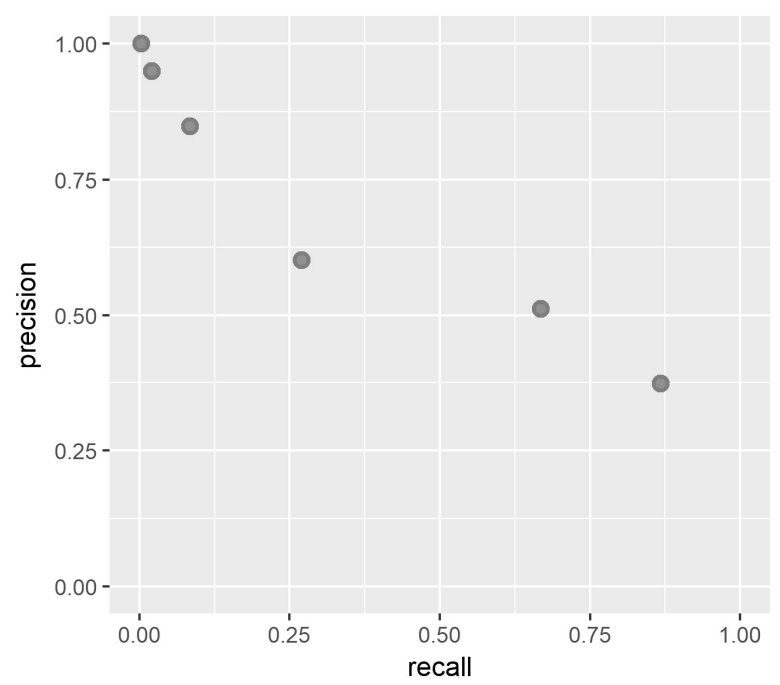

図 3 適合率- 再現率の関係

高い n/N の文字では適合率は高いことか ら一定の 1-gram の有効性が認められた. し かし，n/N を下げた文字を加えていくと， 再現率は高められるが適合率は急激に下が った.この結果から 1-gramによる方法では 一部の化学物質名は選択できるが，す心゙て の化学物質名を高い適合率で選択すること は難しいことがわかった。

表 6には，各抽出条件において抽出され た置換基名の数 $\left(\mathrm{g}_{\mathrm{n}}\right)$ とその他の数 $\left(\mathrm{O}_{\mathrm{n}}\right)$ を示し, 置換基名とその他のそれぞれの再現率，適 合率を示し，図 4に，化学物質名,置換基名 とその他との適合率・再現率の関係をグラ フで示した．置換基名は高い $\mathrm{n} / \mathrm{N}$ では抽出 されず再現率・適合率が低いため化学物質 名の抽出に影響を与えないが， $\mathrm{n} / \mathrm{N}$ が 0.6 以下と選出のしきい值を下げるとその他の
語に比べて再現率が上昇し，影響が出るこ とがわかった。

表 6 置換基名及びその他の抽出状況

\begin{tabular}{|l|r|r|r|r|r|r|}
\hline $\mathrm{n} / \mathrm{N}$ & $\begin{array}{c}\text { 抽出さ } \\
\text { れた置 } \\
\text { 換基名換基 } \\
\text { の数 } \\
\left(\mathrm{g}_{\mathrm{n}}\right)\end{array}$ & $\begin{array}{c}\text { 名再瑍基 } \\
\text { 率 }\end{array}$ & $\begin{array}{c}\text { 抽出さ } \\
\text { 名適合 } \\
\text { 率 } \\
\text { れたその他 }\end{array}$ & $\begin{array}{c}\text { その他 } \\
\text { の他の } \\
\text { 数 }\left(\mathrm{O}_{\mathrm{n}}\right)\end{array}$ & & \\
\hline 1 & 0 & 0.000 & 0.000 & 0 & 0.000 & 0.000 \\
\hline 0.9 & 0 & 0.000 & 0.000 & 18 & 0.000 & 0.051 \\
\hline 0.8 & 39 & 0.013 & 0.025 & 201 & 0.001 & 0.128 \\
\hline 0.7 & 282 & 0.094 & 0.040 & 2548 & 0.016 & 0.359 \\
\hline 0.6 & 1171 & 0.392 & 0.057 & 8888 & 0.055 & 0.431 \\
\hline 0.5 & 2357 & 0.788 & 0.064 & 20683 & 0.129 & 0.562 \\
\hline
\end{tabular}
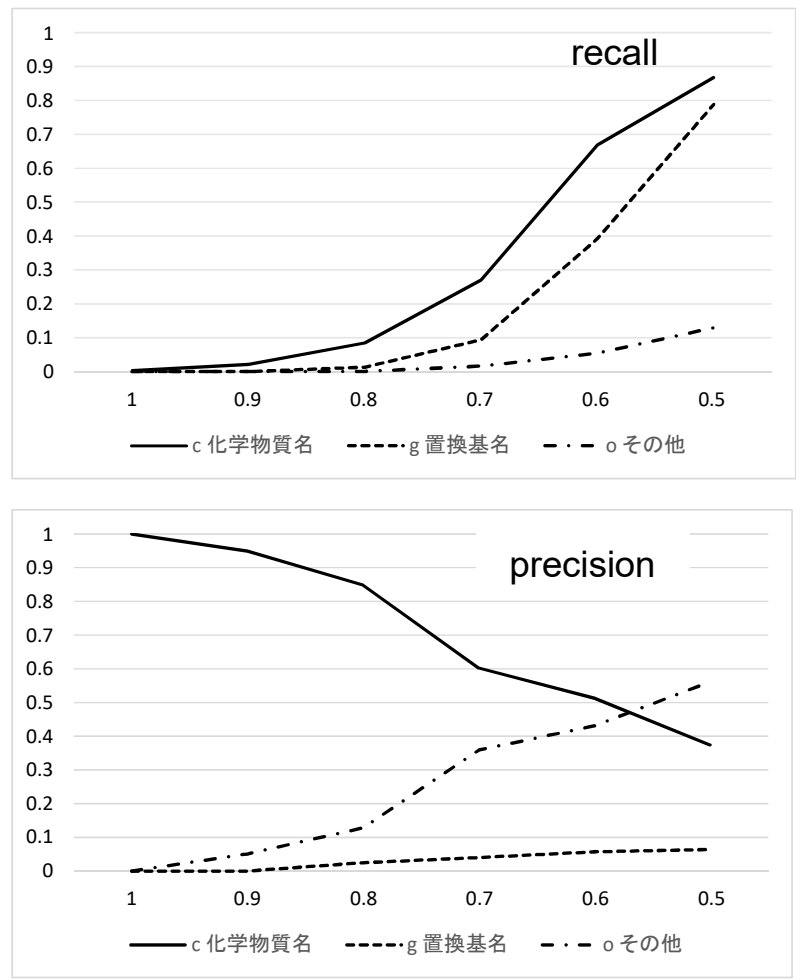

図 4 化合物名, 置換基名, その他の各 $\mathrm{n} / \mathrm{N}$ における適合率・再現率

\section{5 まとめ}

日本語の文章から化学物質名を自動抽出 する方法を検討した。 まず化学物質名の特徴 を見出すために，特許公開公報に手動で化学 物質名 $<$ chem $>$ 及び置換基名 $<$ group $>$ のダ付 けを行った。 日本語の文章から単語を認識す 
るために形態素解析ツールを用いた. 化学物 質名は細かく認識されたため, 品詞の種類や 形態素解析のユーザー辞書を利用して化学 物質名としてひとかたまりの単語となる認 識方法を提案し，その妥当性を明らかにした。 得られた単語が化学物質名か否かを選択寸 る方法として1-gramの適用を検討し，一定の 適合率での抽出が可能であるが，再現率を上 げようとすると急激に適合率が低下寸るた め, 1-gram単独の方法では選出法として妥当 ではないことを明らかにした。また1-gramで は，化学物質名の選出に置換基名が影響を与 えることも合わせて示した. 本研究では, 化 学物質名を正確に単語として認識すること には成功したが, 認識した単語群からの選択 の方法は十分達成できていない. 選択の方法 には1-gramだけでなく2-gramや3-gram, 共起 語, 構文情報や辞書との併用などによる自動 抽出方法が考えられる. また, ビッグデータ の充実から機械学習モデルを用いた認識・選 択も考慮に入れている。この点については今 後の検討課題としたい.

\section{注記および参考文献}

[1] 田中一成ほか:「自然言語処理と

Linked Data を用いた化学物質情報の可 視化」, 言語処理学会 第 24 回年次大会 発 表論文集, pp.1243-1246, 2018

[2] 本論文では文章から化学物質名を含む 単語を切り出すことを認識, その中から化 学物質名を取り出すことを選択といい，そ れらを合わせた操作を抽出という。

[3] 福田賢一郎ほか:「医学生物学文献か らの専門用語の抽出に向けて:タンパク質 名の自動抽出」, 情報処理学会論文誌,

Vol.39, No.8, pp.2421-24330, 1998

[4] Kemp, Nick.; Lynch, Michael.:

"Extraction of Information from the Text of Chemical Patents. 1. Identification of
Specific Chemical Names", J. Chem. Inf. Comput. Sci., Vol. 38, No. 4, pp.544-551, 1998

[5] Zhang, Yaoyun, et al.: "Chemical named entity recognition in patents by domain knowledge and unsupervised feature learning", Database, pp.1-10, 2016 [6]Eltyeb, Safaa; Salim, Naomie:

"Chemical named entities recognition: a review on approaches and applications", Journal of Cheminformatics, pp.6-17, 2014

[7] Krallinger, Martin et al., "Information Retrieval and Text Mining Technologies for Chemistry", Chem. Rev., Vol.117, No.12, pp.7673-7761, 2017

[8] Arighi, Cecilia N. et al.:

"BioCreative-IV virtual issue", Database, https://doi.org/10.1093/database/bau039

Published: 22 May 2014

[9] Krallinger, Martin et al.: "Overview of the CHEMDNER patents task", Proceedings of the Fifth BioCreative Challenge Evaluation Workshop, pp.633-75, 2015

[10] http://www.biocreative.org/tasks/ biocreative-v/track-2-chemdner (2018 年 9 月 17 日参照)

[11］田中一成; 池田紀子：「オープンデー タを用いた化学特許情報活用へのアプロー チ」, Japio YEAR BOOK, pp.206-211, 2017

[12］池田紀子；田中一成：「特許文書から の化学物質情報の抽出」, Japio YEAR

BOOK, pp.280-287, 2015

[13］池田紀子，田中一成：「特許文書から 抽出した化学物質情報の知識化」, Japio YEAR BOOK, pp.204-208, 2016

[14] 石川大介ほか:「特許文献における因 果関係の抽出と統合」, 情報知識学会誌,

Vol.14, No.4, pp.105-118, 2004

[15] https://www.publication.jpo.go.jp/ index.action (2018 年 9 月 17 日参照) [16] http://taku910.github.io/mecab/ (2018 年 9 月 17 日参照)

[17]https://dbarchive.biosciencedbc.jp/jp/ nikkaji/download.html (2018 年 9 月 17 日 参照)

$\begin{array}{ll}\text { (2018年12月 } 16 \text { 日 } & \text { 受付) } \\ \text { (2019年 } 8 \text { 月 } 31 \text { 日 } & \text { 採択) }\end{array}$ 